\title{
Sexual function and depressive symptoms in men with overt hyperthyroidism
}

\author{
Funkcjonowanie seksualne i objawy depresyjne u mężczyzn z jawną \\ nadczynnością tarczycy
}

\author{
Robert Krysiak', Bogdan Marek ${ }^{2,3}$, Bogusław Okopieńn \\ ${ }^{1}$ Department of Internal Medicine and Clinical Pharmacology, Medical University of Silesia, Katowice, Poland \\ ${ }^{2}$ Division of Pathophysiology, Department of Pathophysiology and Endocrinology, Medical University of Silesia, Zabrze, Poland \\ ${ }^{3}$ Endocrinological Ward, Third Provincial Hospital, Rybnik, Poland
}

\begin{abstract}
Introduction: Although hyperthyroidism is characterised by female predominance, its presence may lead to the development of numerous complications in both sexes. This study was aimed at investigating sexual function and depressive symptoms in men with overt hyperthyroidism of autoimmune and non-autoimmune origin.

Material and methods: The study population consisted of three age-matched groups: men with overt hyperthyroidism and Graves' disease (group $A ; n=20$ ), men with overt hyperthyroidism and toxic multinodular goitre or toxic adenoma (group B; $n=21$ ), and men with normal thyroid function (group $C ; n=23$ ). As well as measuring serum hormone levels and antibody titres, and determining calculated parameters of thyroid homeostasis, all included patients filled in questionnaires evaluating sexual function (International Index of Erectile Function-15: IIEF-15) and assessing the presence and severity of depressive symptoms (Beck Depression Inventory-Second Edition - BDI-II). Results: Compared with control subjects, men with overt hyperthyroidism obtained lower scores for erectile function, intercourse satisfaction, orgasmic function and overall satisfaction. Scores for erectile function, orgasmic function, and sexual desire differed between both groups of men with thyroid hyperfunction and inversely correlated with thyrotropin receptor antibody titres. The BDI-II score was higher in patients with Graves' disease than in men with normal thyroid function.

Conclusions: The obtained results indicate that overt hyperthyroidism in men causes multidimensional impairment of sexual function, which is particularly pronounced if excessive hormone production results from Graves' disease. (Endokrynol Pol 2019; 70 (1): 64-71)
\end{abstract}

Key words: depressive symptoms; Graves' disease; hyperthyroidism; sexual functioning; thyroid nodules

\section{Streszczenie}

Wprowadzenie: Chociaż nadczynność tarczycy występuje częściej u kobiet niż mężczyzn, obecność tego schorzenia powodować może wystąpienie licznych powikłań u obu płci. Celem badania była ocena funkcjonowania seksualnego i objawów depresyjnych u mężczyzn z jawną nadczynnością tarczycy o podłożu autoimmunologicznym i nieautoimmunologicznym.

Materiał i metody: Badaną populację stanowiły trzy grupy mężczyzn w porównywalnym wieku: mężczyźni z jawną nadczynnością tarczycy na tle choroby Gravesa i Basedowa (grupa $A, n=20$ ), mężczyźni z jawną nadczynnością tarczycy spowodowaną wolem wieloguzkowym lub pojedynczym gruczolakiem (grupa B, n = 21) oraz mężczyźni z prawidłową funkcją hormonalną tarczycy (grupa C, $\mathrm{n}=23$ ). Poza oceną stężeń hormonów w surowicy, zbadaniem miana przeciwciał i wyliczeniem wartości strukturalnych wskaźników homeostazy tarczycowej, uczestnicy badania wypełnili kwestionariusze oceniające funkcjonowanie seksualne (IIEF-15) oraz obecność i nasilenie objawów depresyjnych (BDI-II).

Wyniki: W porównaniu z grupą kontrolną mężczyźni z jawną nadczynnością tarczycy charakteryzowali się niższą punktacją w zakresie: funkcji erekcyjnej, satysfakcji ze stosunku, jakości orgazmu i całkowitej satysfakcji seksualnej. Punktacja w zakresie: funkcji erekcyjnej, jakości orgazmu i pożądania różniła się między obiema grupami mężczyzn z nadczynnością tarczycy, wykazując ujemną korelację z mianem przeciwciał przeciwko receptorowi dla TSH. Globalna wartość wskaźnika BDI-II była wyższa u osób z chorobą Gravesa-Basedowa w porównaniu z grupą kontrolną.

Wnioski: Uzyskane wyniki wskazują, że jawna nadczynność tarczycy powoduje wielokierunkowe zaburzenia funkcjonowania seksualnego u mężczyzn, szczególnie silnie wyrażone w przypadku nadczynności spowodowanej przez chorobę Gravesa i Basedowa. (Endokrynol Pol 2019; 70 (1): 64-71)

Słowa kluczowe: objawy depresyjne; choroba Gravesa i Basedowa; nadczynność tarczycy; funkcjonowanie seksualne; guzki tarczycy 


\section{Introduction}

Hyperthyroidism, defined as the excess production and release of thyroid hormone by the thyroid gland, is one of the most common endocrine disorders in developed countries [1]. In the United States, the prevalence of hyperthyroidism is approximately 1.2\% [2], and in Europe $0.8 \%$ [3]. Thyroid hyperfunction is caused mainly by Graves' disease, toxic multinodular goitre, and toxic adenoma [4,5]. Despite a clear female preponderance, men may also suffer from this disorder. In Europe, the prevalence of overt and subclinical hyperthyroidism in men is estimated at $0.48 \%$ and $1.97 \%$, respectively, while the incidence rate of thyroid hyperfunction is calculated to be 72.48 per 100,000 [3]. Irrespective of gender, a disproportionate amount of thyroid hormone leads to an accelerated metabolic state, causing significant morbidity and mortality [6].

The results of some studies conducted to date suggest that thyroid disorders may have an unfavourable effect on sexual functioning in men. The most characteristic abnormality related to this clinical entity is acquired premature ejaculation [7-9]. Hyperthyroidism is also associated with the presence of erectile dysfunction, including its severe form [9-12]. This relationship did not change after adjusting for age, which suggests that inappropriate thyroid hormone levels are probably more important than age in inducing erectile dysfunction $[11,12]$. Unlike hypothyroidism, the association between hyperthyroidism and impaired erectile functioning was also found to be independent of other potential confounders including age, body mass index, blood pressure, other hormones, and serum lipids [11]. Interestingly, both the risk of premature ejaculation and erectile dysfunction was reduced by treating the underlying disease [8-10]. Thyroid overactivity, although to a lesser extent than hypothyroidism, may also predispose to the development of hypoactive sexual desire [9]. Finally, thyroid hormone overproduction induces a decrease in total seminal volume and total sperm count, increases the percentage of dead sperm, and disturbs progressive mobility, lineal progressive motility, and sperm morphology [13]. Unfortunately, the clinical significance of these findings is seriously limited by methodological problems, the fact that participants knew their thyroid status, and by analysing only some aspects of men's sexual response.

Recently we have shown that the impact of subclinical thyroid hypofunction on sexual functioning and on mood in women was stronger if hypothyroidism was secondary to Hashimoto's thyroiditis [14]. Because of the lack of similar data in hyperthyroidism, in the current study we have compared various aspects of male sexual functioning and depressive symptoms between men with frank hyperthyroidism of either autoimmune (Graves' disease) or non-autoimmune (thyroid nodular disease) origin and a matched group of men with intact hypothalamic-pituitary-thyroid axis activity.

\section{Material and methods}

\section{Study population}

The participants of the study were recruited among adult men (20-60 years old) with symptoms or signs suggestive of hyperthyroidism (weight loss, tachycardia, intolerance to heat, excessive sweating, or diarrhoea). The patients were eligible for the study if they met the following criteria of overt hyperthyroidism: serum thyrotropin levels below $0.1 \mathrm{mIU} / \mathrm{L}$, serum free thyroxine levels above $23 \mathrm{pmol} / \mathrm{L}$, and/or free triiodothyronine levels above $6.5 \mathrm{pmol} / \mathrm{L}$. Based on serum titres of thyrotropin receptor antibodies (TRAb) and thyroid ultrasound imaging characteristics, they were enrolled into one of two groups: group A including 20 patients with Graves' disease (TRAb titres above $1.8 \mathrm{U} / \mathrm{L})$ or group $B$ including 21 men with either toxic multinodular goitre $(n=11)$ or toxic adenoma $(n=10)$. The control group consisted of 23 men screened for the presence of hyperthyroidism, in whom thyrotropin and free thyroid hormone levels were within the reference range.

The subjects were excluded if they met at least one of the following criteria: the presence of both TRAb and thyroid nodules, other forms of overt hyperthyroidism; subclinical hyperthyroidism; euthyroid sick syndrome; thyroid cancer; type 1 or type 2 diabetes; hyperprolactinaemia; hypogonadism; osteoporosis; prostate, cardiovascular, neurologic, or psychiatric disorders; impaired renal or hepatic function; acute or chronic infection; abnormal rectal bleeding; developmental or acquired anomalies of the male reproductive system; a past history of myocardial infarction or acute cerebrovascular events; a past history of total or transurethral prostatectomy; a past history of major pelvic surgery or of other operations that might have affected sexual function; sexual inactivity; and any pharmacotherapy.

All subjects gave written, informed consent to participate in the study, and the study protocol was approved by the Local Ethics Committee.

\section{Laboratory assays}

Venous blood samples were taken $12 \mathrm{~h}$ after the last meal in a quiet, temperature-controlled room $\left(24-25^{\circ} \mathrm{C}\right)$. To avoid possible circadian fluctuations in the parameters studied, samples were drawn during constant daily hours (between 8.00 and 9.00 a.m.), and to minimise analytical errors, all assays were performed in duplicate. Before submission of our manuscript, we 
also retrospectively measured serum levels of free testosterone and prolactin in 12 randomly selected stored serum samples from each study group. All tests were performed in blinded fashion by persons unaware of patient characteristics. Serum levels of thyrotropin, free thyroxine, free triiodothyronine, and prolactin, as well as titres of thyroid peroxidase antibodies (TPOAb) were determined by direct chemiluminescence using acridinium ester technology (ADVIA Centaur XP Immunoassay System, Siemens Healthcare Diagnostics, Munich, Germany). Circulating levels of free testosterone were determined by enzyme-linked immunosorbent assay using a EUROIMMUN analyser I (Euroimmun, Wrocław, Poland). Titres of TRAb were measured by immunoassay with chemiluminescent detection (Immulite 2000XPi, Siemens Healthcare, Warsaw, Poland). Parameters of thyroid homeostasis: Jostel's thyrotropin, structure parameter inference approach (SPINA)GT and SPINA-GD indices were calculated using SPINA-Thyr 4.0.1 for Windows software according to the formulas described previously [15-17].

\section{Questionnaires}

Immediately after collecting blood samples and the ultrasound, the participants were asked to complete three questionnaires. The first questionnaire assessed their demographic characteristics, smoking, physical activity, education, occupation, stress exposure, number of sexual partners, and number and duration of marriages. The second questionnaire (the International Index of Sexual Function-15 - IIEF-15 for heterosexual men) evaluated sexual functioning, while the third one (Beck Depression Inventory-Second Edition - BDI-II) evaluated depressive symptoms.

IIEF-15 is self-administered questionnaire, composed of 15 items, regarded as a reliable, cross-culturally valid, and psychometrically sound measure of male sexual function [18, 19]. The items evaluate five relevant domains of male sexual functioning in the previous four weeks: erectile function (questions 1-5 and 15), intercourse satisfaction (questions 6-8), orgasmic function (questions 9 and 10), sexual desire (questions 11 and 12), and overall satisfaction (questions 13 and 14). Questions are scored on a five-point or six-point Likert scale, with responses ranging from 0 to 5 or 1 to 5 . Minimum scores were: 0 for intercourse satisfaction and orgasmic function, 1 for erectile function, and 2 for sexual desire and overall satisfaction. Maximum scores were: 10 for orgasmic function, sexual desire and overall satisfaction, 15 for intercourse satisfaction, and 30 for erectile function. The severity of erectile dysfunction was classified into five categories: no erectile dysfunction (score 26 to 30), mild erectile dysfunction (score 22 to 25), mild to moderate erectile dysfunction (score 17 to 21), moderate erectile dysfunction (score 11 to 16), and severe erectile dysfunction (score 6 to 10) [18-20].

BDI-II is a self-rating scale with 21 items, which are focused on depression symptoms: affective, motivational, cognitive, and physiological during the previous two weeks [21-23]. The items have been adjusted to measure depressive symptoms corresponding with the diagnostic criteria for depressive disorders outlined in the Diagnostic and Statistical Manual of Mental Disorders, Fourth Edition [24]. Each item is rated on a four-point scale from 0 (not present) to 3 (severe). The overall score ranges from 0 to 63 , with higher values indicating more severe depressive symptoms. The BDI-II score from 14 to 19 points is interpreted as mild depression, from 20 to 28 as moderate depression, and from 29 to 63 as severe depression [21-23].

\section{Statistical analysis}

Because of skewed distributions, all parameters were natural-log transformed to meet the assumptions of parametric tests. Between-group comparisons were performed using analysis of covariance followed by Bonferroni post hoc tests after consideration of age, smoking, body mass index, waist circumference, marital status, education, occupational activity, type of work, profession, physical activity, and stress exposure, as well as blood pressure as potential confounders. The $\chi^{2}$ test was employed to compare the proportional data. Correlations were assessed using the Pearson partial correlation coefficient (r). Statistical significance was assumed at $\mathrm{p}<0.05$.

\section{Results}

\section{General characteristics of the study groups}

There were no differences between the study groups in age, smoking (the number of cigarettes and duration of smoking), education, occupational activity, type of work, number of sexual partners, number and duration of marriages, and stress exposure. Men with thyroid hyperfunction differed from men with normal thyroid function in body mass index, physical activity, and blood pressure (Tab. I).

As expected, there were differences between men with hyperthyroidism and subjects with normal thyroid function in serum levels of thyrotropin and free thyroid hormones, as well as between men with Graves' disease and the remaining groups of patients in serum titres of TRAb and TPOAb. Jostel's thyrotropin index was lower, while the SPINA-GT and SPINA-GD indices were higher in groups A and B than in group C. Levels of free triiodothyronine and the SPINA-GD index were higher in group A than in group B. Serum levels of free 
Table I. Sociodemographic characteristics of the study population

Tabela I. Wyjściowa charakterystyka uczestników badania

\begin{tabular}{lccc}
\hline & Group A & Group B & Group C $^{2}$ \\
\hline Number of patients & 20 & 21 & 23 \\
\hline Age [years; mean (SD)] & $47(8)$ & $49(7)$ & $50(7)$ \\
\hline Body mass index [kg/m²; mean (SD)] & $21.8(3.8)^{\mathrm{d}}$ & $22.0(3.5)^{\mathrm{d}}$ & $26.7(4.9)$ \\
\hline $\begin{array}{l}\text { Smokers (\%)/Number of cigarettes a day [n; mean (SD)]/ } \\
\text { /Duration of smoking [years, mean (SD)] }\end{array}$ & $35 / 15(8) / 20(10)$ & $29 / 14(9) / 22(12)$ & $30 / 14(7) / 23(11)$ \\
\hline $\begin{array}{l}\text { Physical activity: total/once a week/several times a week/ } \\
\text { /once a month (\%) }\end{array}$ & $35 / 15 / 0 / 20^{\mathrm{c}}$ & $38 / 24 / 0 / 13^{\mathrm{c}}$ & $100 / 48 / 43 / 9$ \\
\hline Primary or vocational/secondary/university education (\%) & $20 / 40 / 40$ & $19 / 43 / 38$ & $22 / 39 / 39$ \\
\hline Occupational activity/blue-collar/white-collar/pink-collar workers (\%) & $100 / 45 / 55 / 0$ & $95 / 43 / 52 / 0$ & $100 / 43 / 57 / 0$ \\
\hline Number of sexual partners [n; mean (SD)] & $3.1(1.1)$ & $3.0(1.0)$ & $2.8(1.0)$ \\
\hline $\begin{array}{l}\text { Number of marriages [n; mean (SD)]/duration of marriages } \\
\text { [months; years (SD)] }\end{array}$ & $1.4(0.7) / 18(7)$ & $1.4(0.8) / 19(8)$ & $1.3(0.8) / 20(9)$ \\
\hline Stress exposure [\%, mean (SD)] & 80 & & 76 \\
\hline Systolic blood pressure [mmHg; mean (SD)] & $137(12)^{\mathrm{b}}$ & $135(12)^{\mathrm{a}}$ & $127(10)$ \\
\hline Diastolic blood pressure [mmHg; mean (SD)] & $75(7)^{\mathrm{c}}$ & $77(8)^{\mathrm{b}}$ & $84(6)$ \\
\hline
\end{tabular}

${ }^{1}$ Men with overt hyperthyroidism and Graves' disease; ${ }^{2}$ Men with overt hyperthyroidism and toxic multinodular goitre or toxic adenoma; ${ }^{3} \mathrm{Men}$ with normal thyroid function; ${ }^{a} p<0.05,{ }^{b} p<0.01,{ }^{c} p<0.001$ vs. group $B ;{ }^{d} p<0.001$ vs. group $\mathrm{C} ; \mathrm{SD}-$ standard deviation

Table II. Serum hormone levels, antibody titres, and thyroid function tests in the study population

Tabela II. Stężenie hormonów, miano przeciwciał i strukturalne wskaźniki homeostazy tarczycowej uczestników badania

\begin{tabular}{lccc}
\hline Variable & Group A $^{1}$ & Group B $^{2}$ & Group C $^{3}$ \\
\hline Thyrotropin [mlU/L; mean (SD)] & $0.016(0.012)^{\mathrm{d}}$ & $0.018(0.016)^{\mathrm{d}}$ & $1.345(0.945)$ \\
\hline Free thyroxine [pmol/L; mean (SD)] & $37.5(6.7)^{\mathrm{d}}$ & $38.2(6.2)^{\mathrm{d}}$ & $16.0(3.4)$ \\
\hline Free triiodothyronine [pmol/L; mean (SD)] & $18.7(6.0)^{\mathrm{b}, \mathrm{d}}$ & $12.8(3.9)^{\mathrm{d}}$ & $4.2(1.2)$ \\
\hline Thyrotropin receptor antibodies [U/L; mean (SD)] & $6.2(2.0)^{\mathrm{b}, \mathrm{d}}$ & $0.1(0.1)$ & $0.1(0.1)$ \\
\hline Thyroid peroxidase antibodies [U/mL; mean (SD)] & $205(194)^{\mathrm{b}, \mathrm{d}}$ & $14(9)$ & $15(10)$ \\
\hline Jostel's thyrotropin index [mean (SD)] & $0.9(0.3)^{\mathrm{d}}$ & $1.1(0.3)^{\mathrm{d}}$ & $2.4(0.4)$ \\
\hline SPINA-GT index [pmol/s; mean (SD)] & $492.12(85.65)^{\mathrm{d}}$ & $445.92(68.94)^{\mathrm{d}}$ & $3.70(0.82)$ \\
\hline SPINA-GD index [nmol/s; mean (SD)] & $46.11(7.81)^{\mathrm{b}, \mathrm{d}}$ & $30.98(5.74)^{\mathrm{d}}$ & $24.27(3.28)$ \\
\hline Prolactin $[\mu \mathrm{g} / \mathrm{L} ;$ mean (SD) & $10(4)$ & $10(5)$ & $11(6)$ \\
\hline Free testosterone [pmol/L; mean (SD)] & $270(59)^{\mathrm{a}, \mathrm{c}}$ & $328(82)$ & $316(68)$ \\
\hline
\end{tabular}

${ }^{1}$ Men with overt hyperthyroidism and Graves' disease; ${ }^{2}$ Men with overt hyperthyroidism and toxic multinodular goitre or toxic adenoma; ${ }^{3}$ Men with normal thyroid function; ${ }^{4}$ Data of 12 men from each group; ${ }^{a} p<0.05$, ${ }^{b} p<0.001$ vs. group $B ;{ }^{c} p<0.05,{ }^{d} p<0.001$ vs. group C; SD - standard deviation

testosterone were lower in group A than in groups B and C (Tab. II).

\section{Assessment of sexual function}

The study groups differed in the percentage of patients with erectile dysfunction. In group A, mild, mild to moderate, moderate, and severe erectile dysfunction was found in three $(15 \%)$, six $(30 \%)$, six $(30 \%)$, three $(15 \%)$, and two subjects (10\%), respectively. In group B, six men (29\%) had mild, four men (19\%) had mild to moderate, two men $(10 \%)$ had moderate, and one man $(5 \%)$ had severe erectile dysfunction. In group
C, five subjects $(22 \%)$ had mild while one man $(4 \%)$ had mild to moderate erectile dysfunction. Compared with group $\mathrm{C}$, men with overt hyperthyroidism obtained lower scores for erectile function, intercourse satisfaction, orgasmic function, and overall satisfaction. Scores for erectile function, orgasmic function, and desire were lower in group A than in group B (Tab. III).

\section{Assessment of depressive symptoms}

The overall BDI-II score was higher in group A than in group $\mathrm{C}$, and was insignificantly higher in group 
Table III. Sexual function in the study population

Tabela III. Funkcjonowanie seksualne uczestników badania

\begin{tabular}{lccc}
\hline Variable & Group A & Group B $^{2}$ & Group C $^{3}$ \\
\hline Erectile function [mean (SD)] & $18.9(6.4)^{\mathrm{a}, \mathrm{d}}$ & $22.5(4.8)^{\mathrm{c}}$ & $26.3(2.4)$ \\
\hline Erectile dysfunction [\%] & $85^{\mathrm{a}, \mathrm{d}}$ & $62^{\mathrm{c}}$ & 26 \\
\hline Intercourse satisfaction [mean (SD)] & $11.6(2.3)^{\mathrm{c}}$ & $11.8(2.1)^{\mathrm{b}}$ & $13.2(1.5)$ \\
\hline Orgasmic function [mean (SD)] & $6.9(1.1)^{\mathrm{a}, \mathrm{d}}$ & $7.8(1.3)^{\mathrm{c}}$ & $8.8(1.0)$ \\
\hline Sexual desire [mean (SD)] & $7.5(1.4)^{\mathrm{a}, \mathrm{b}}$ & $8.4(1.4)$ & $8.2(1.6)$ \\
\hline Overall satisfaction [mean (SD)] & $7.4(1.4)^{\mathrm{c}}$ & $7.7(1.5)^{\mathrm{b}}$ & $8.7(1.5)$ \\
\hline
\end{tabular}

${ }^{1}$ Men with overt hyperthyroidism and Graves' disease; ${ }^{2}$ men with overt hyperthyroidism and toxic multinodular goitre or toxic adenoma; ${ }^{3}$ Men with normal thyroid function; ${ }^{a} p<0.05$ vs. group $B,{ }^{b} p<0.05,{ }^{c} p<0.01,{ }^{d} p<0.001$ vs. group $C$; $S D-$ standard deviation

Table IV. Depressive symptoms in the study population

Tabela IV. Objawy depresyjne uczestników badania

\begin{tabular}{lccc}
\hline Variable & Group A & Group B $^{2}$ & Group C $^{3}$ \\
\hline BDI-Il score [mean (SD)] & $12.3(4.7)^{\mathrm{b}}$ & $9.8(4.9)$ & $7.2(3.8)$ \\
\hline Depressive symptoms [n (\%)] & $8(40)^{\mathrm{a}}$ & $5(24)$ & $2(9)$ \\
\hline Mild symptoms [n (\%)] & $8(40)^{\mathrm{a}}$ & $5(24)$ & $2(9)$ \\
\hline Moderate symptoms [n (\%)] & $0(0)$ & $1(6)$ & $0(0)$ \\
\hline Severe symptoms [n (\%)] & $0(0)$ & $0(0)$ & $0(0)$ \\
\hline
\end{tabular}

${ }^{1}$ Men with overt hyperthyroidism and Graves' disease; ${ }^{2}$ Men with overt hyperthyroidism and toxic multinodular goitre or toxic adenoma; ${ }^{3}$ Men with normal thyroid function; ${ }^{a} p<0.01,{ }^{b} p<0.001$ vs. group $C ; S D-$ standard deviation

A than in group B $(p=0.092)$ and in group B than in group $C(p=0.055)$. The percentage of men with total and mild depressive symptoms was higher in group A than in group $C$. The study groups did not differ in the percentage of patients with moderate and severe depressive symptoms (Tab. IV).

\section{Correlations}

In all study groups, erectile function, intercourse satisfaction, orgasmic function, sexual desire, and overall satisfaction inversely correlated with the total BDI-II score ( $r$ values between -0.29 [ $p<0.05$ ] and -0.49 [ $<<0.001$ ]; group B: r values between -0.26 [ $p<0.05$ ] and -0.47 [ $<<0.001$ ]; group $\mathrm{C} r$ values between -0.28 [p $<0.05]$ and -0.42 [p $<0.001])$. There were also positive correlations between sexual desire ( $\mathrm{r}$ values between 0.40 [ $p<0.001]$ and 0.51 [ $p<0.001]$ ), and, to a lesser extent, other domains of sexual functioning $(\mathrm{r}$ values between $0.23[p<0.05]$ and $0.35[p<0.01])$, and free testosterone levels. In group A, erectile function, orgasmic function, and sexual desire negatively correlated with serum titres of TRAb ( $\mathrm{r}$ values between -0.32 [p $<0.05]$ and -0.46 [p $<0.001]$ ) or TPOAb ( $\mathrm{r}$ values between -0.25 [ $<<0.05$ ] and -0.37 [ $<0.01]$ ), while BDI-II score positively correlated with antibody titres (TRAb: $\mathrm{r}=0.35, \mathrm{p}<0.01$; TPOAb: $\mathrm{r}=0.38, \mathrm{p}<0.001$ ). In subjects with overt hyperthyroidism, erectile func- tion, intercourse satisfaction, orgasmic function, sexual desire, and overall satisfaction positively correlated with serum levels of thyrotropin (group A: $r$ values between 0.28 [ $<<0.05]$ and $0.42[p<0.001]$; group B: r values between $0.24[p<0.05]$ and $0.41[p<0.001])$ and negatively with serum levels of free thyroid hormones, SPINA-GT index, and SPINA-GD index (group A: $r$ values between -0.28 [ $p<0.05]$ and -0.46 [ $<<0.001]$; group B: $r$ values between $-0.26[p<0.05]$ and -0.42 [p $<0.001])$. In all study groups, there were also correlations (a) between the mean BDI-II score and the body mass index ( $\mathrm{r}$ values between 0.31 [ $\mathrm{p}<0.05$ ] and 0.42 [p < 0.001]), (b) between the mean BDI-II score and physical activity ( $\mathrm{r}$ values between -0.28 [ $p<0.05$ ] and -0.34 [p $<0.05]$ ), and (c) between the mean BDI-II score and systolic blood pressure ( $r$ values between 0.26 [ $p<0.05$ ] and 0.36 [ $<<0.01])$. No other correlations were found.

\section{Discussion}

This study has shown for the first time that clinically overt hyperthyroidism causes multidimensional impairment of male sexual function, which is accompanied by relatively mild depressive symptoms. A strong point of our study is that, because of strict inclusion and exclusion criteria, the population was a relatively 
homogeneous group of drug-naïve men. Moreover, differences between hyperthyroid and euthyroid men could not have been attributed to signs and symptoms experienced by the participants of the study because both individuals with hyperthyroidism and control subjects with normal thyroid function were selected from among men complaining of weight loss, tachycardia, intolerance to heat, excessive sweating, and/or diarrhoea. Finally, in contrast to most conducted studies, at the time of filling in all questionnaires neither the participants nor the investigators knew the results of the laboratory examinations (blood sampling and subsequent diagnosis were performed at the same time as completing the questionnaires). This eliminated the possibility that the participants were aware of their thyroid status, which might have made the obtained results highly questionable.

We have found numerous correlations between various aspects of male sexual functioning and thyrotropin levels, free thyroid hormone levels, and the SPINA-GT, estimating the maximum secretion rate of the thyroid gland under stimulated conditions [16, 17]. These findings suggest the impact of excessive amounts of thyroid hormones on brain structures involved in sexual behaviour and feelings and on sexual organs. This effect may be partially direct because both human and animal smooth muscle cells isolated from corpus cavernosum were found to express both types of thyroid hormone receptors (TR and TR) [25]. Moreover, thyroid hormone excess reduced nitric oxide production in the penile corpus cavernosum [26], as well as impaired endothelium-dependent (and neurogenic) relaxation of corporal smooth muscle [27]. These mechanisms may contribute to the development of impotence in the study population. However, taking into account that the mentioned correlations were at most moderate, it seems that the effect of hyperthyroidism on sexual function is also indirectly mediated by other mechanisms. One of them may be the impact on synthesis, protein binding and metabolism of testosterone [28]. In line with this hypothesis, free testosterone levels, representing a biologically relevant fraction of this hormone [29], correlated with all domains of male sexual functioning evaluated in our study. The finding that this correlation was strongest for desire is in agreement with the fact that hormones play a greater role in regulating libido than in the regulation of other domains of human sexual response, assessed by IIEF-15 questionnaire [30]. Therefore, it is possible that relatively high testosterone levels in men with toxic multinodular goitre or toxic adenoma might have reversed the direct negative impact of thyroid hormone overproduction on libido, explaining why, unlike other domains, desire in this study group did not differ from that observed in the control subjects. On the other hand, the lack of analogical correlations for prolactin, as well as its similar levels in all study groups, suggest that prolactin does not mediate the effect of hyperthyroidism on male sexual behaviour.

Another important finding of the study was that some sexual disturbances (and depressive symptoms) were more frequent and more severe in men with Graves' disease than in nodular thyroid disease. The former one is an organ-specific autoimmune thyroid disease responsible for most cases of thyroid hormone overproduction in developed countries [31]. Interestingly, the same relationship between the severity of sexual dysfunction and a disease causing hyperthyroidism was recently observed by our research team in women (Krysiak et al., unpublished observation). Worse sexual functioning in men with Graves' disease than in men with nodular thyroid disease seems to be associated with differences in hormone production and metabolism. In line with this explanation, patients with Graves' disease were characterised by higher levels of triiodothyronine and a higher value of the SPINA-GD, reflecting deiodinase activity and thyroxine:triiodothyronine conversion efficiency [16, 17], as well as by lower levels of free testosterone. However, differences in erectile function, orgasmic function and sexual desire may be also attributed to the effect of autoimmunity. According to this explanation, TRAb and $\mathrm{TPOAb}$ antibody titres correlated with domain scores for erectile function, orgasmic function, and desire, but not with domain scores for intercourse satisfaction and overall satisfaction, which were similar in patients with Graves' disease and thyroid nodular disease. Also, the finding that even euthyroid patients with Hashimoto's thyroiditis were characterised by disturbances in desire, lubrication, and sexual satisfaction [14], indicates that autoimmune thyroid disorders may make subjects more prone to sexual dysfunction. Because free testosterone correlated with triiodothyronine and the SPINA-GD, but not with antibody titres, statistically significant differences in its levels between men with Graves' disease and men with thyroid nodular disease should be interpreted as secondary to thyroid hormone production and peripheral metabolism rather than be directly related to autoimmune process.

Beyond sexual dysfunction, men with thyroid hyperfunction, particularly subjects with Graves' disease, were characterised by mood disturbances. The obtained results are in agreement with findings of other authors [32], who observed a significantly higher symptom level of depression in women and men with Graves' disease compared to patients with nodular goitre. The fact that the overall BDI-II score correlated with all domain scores of IIEF indicates that male sexual functioning and depressive symptoms are reciprocally related 
but does not allow us to determine whether depressive symptoms reflect sexual dysfunction or impaired sexual functioning plays a role in the development of these symptoms. The increased overall BDI-II score, as well as a higher percentage of men with total and mild depressive symptoms, may be associated with the proinflammatory state, characteristic for Graves' disease [33], which seems to contribute to the development of depression [34]. In line with this hypothesis, TRAb and $\mathrm{TPOAb}$ titres in our study correlated with the BDI-II score. The remaining potential mechanisms implicated in this relationship include a direct effect of thyroid hormone excess on the limbic system, the impact of thyroid overactivity on adrenergic neurotransmission in the central nervous system, as well as the effect of hyperthyroidism on hypothalamic-pituitary-adrenal axis activity [35]. Moreover, as other correlations suggest, the increased symptom level of depression in the investigated population of hyperthyroid men was also associated with the presence of other factors, including higher values of systolic blood pressure, reduced physical activity, and self-perception of weight.

There are some shortcomings that may limit the generalisability of our findings. The study groups included a relatively small number of patients, and therefore the results need to be confirmed in a larger population of patients. The study was carried out in the Upper Silesia, which is a selenium-deficient [36] and, because of mandatory salt iodisation, iodine-sufficient [37] area. It remains unsolved whether the impact of thyroid overactivity on sexual functioning and depressive symptoms is the same in men in whom selenium supply is sufficient and/or iodine supply is insufficient. The study protocol does not allow us to conclude whether and to what extent male sexual functioning and mood are disturbed in subjects with subclinical hyperthyroidism, not included in our study. Finally, although the IIEF-15 and BDI-II questionnaires are well-validated, their utility is limited by subjectivity.

\section{Conclusions}

In conclusion, men with overt hyperthyroidism were characterised by disturbances in almost all aspects of male sexual functioning assessed by the IIEF questionnaire (erectile function, intercourse satisfaction, orgasmic function, and overall satisfaction) and by relatively small changes in mood. Individuals with Graves' disease differed from men with hyperthyroidism of non-autoimmune hyperthyroidism in desire, erectile function, and orgasmic function. The obtained results suggest that overt hyperthyroidism, particularly resulting from Graves' disease, impairs male sexual functioning and may lead to a worsening of mood.

\section{Conflict of interest}

The authors declare no conflict of interest.

\section{Acknowledgements}

The study was not supported by any specific grant. The experiments comply with the current law of Poland.

\section{References}

1. Ross DS, Burch HB, Cooper DS, et al. 2016 American Thyroid Association Guidelines for Diagnosis and Management of Hyperthyroidism and Other Causes of Thyrotoxicosis. Thyroid. 2016; 26(10): 1343-1421, doi: 10.1089/thy.2016.0229, indexed in Pubmed: 27521067.

2. Hollowell JG, Staehling NW, Flanders WD, et al. Serum TSH, T(4), and thyroid antibodies in the United States population (1988 to 1994): National Health and Nutrition Examination Survey (NHANES III). J Clin Endocrinol Metab. 2002; 87(2): 489-499, doi: 10.1210/jcem.87.2.8182, indexed in Pubmed: 11836274.

3. Garmendia Madariaga A, Santos Palacios S, Guillén-Grima F, et al. The incidence and prevalence of thyroid dysfunction in Europe: a meta-analysis. J Clin Endocrinol Metab. 2014; 99(3): 923-931, doi: 10.1210/jc.2013-2409, indexed in Pubmed: 24423323.

4. Kravets I. Hyperthyroidism: Diagnosis and Treatment. Am Fam Physician. 2016; 93(5): 363-370, indexed in Pubmed: 26926973.

5. De Leo S, Lee SY, Braverman LE. Hyperthyroidism. Lancet. 2016; 388(10047): 906-918, doi: 10.1016/S0140-6736(16)00278-6, indexed in Pubmed: 27038492

6. Devereaux D, Tewelde SZ. Hyperthyroidism and thyrotoxicosis. Emerg Med Clin North Am. 2014; 32(2): 277-292, doi: 10.1016/j.emc.2013.12.001, indexed in Pubmed: 24766932

7. Cihan A, Demir O, Demir T, et al. The relationship between premature ejaculation and hyperthyroidism. J Urol. 2009; 181(3): 1273-1280, doi: 10.1016/j.juro.2008.10.150, indexed in Pubmed: 19185321.

8. McMahon CG, Jannini EA, Serefoglu EC, et al. The pathophysiology of acquired premature ejaculation. Transl Androl Urol. 2016; 5(4): 434-449, doi: 10.21037/tau.2016.07.06, indexed in Pubmed: 27652216.

9. Carani C, Isidori AM, Granata A, et al. Multicenter study on the prevalence of sexual symptoms in male hypo- and hyperthyroid patients. J Clin Endocrinol Metab. 2005; 90(12): 6472-6479, doi: 10.1210/jc.2005-1135, indexed in Pubmed: 16204360.

10. Krassas GE, Tziomalos K, Papadopoulou F, et al. Erectile dysfunction in patients with hyper- and hypothyroidism: how common and should we treat? J Clin Endocrinol Metab. 2008; 93(5): 1815-1819, doi: 10.1210/jc.2007-2259, indexed in Pubmed: 18270255.

11. Corona G, Wu FCW, Forti G, et al. EMAS Study Group. Thyroid hormones and male sexual function. Int J Androl. 2012; 35(5): 668-679, doi: 10.1111/j. 1365-2605.2012.01266.x, indexed in Pubmed: 22834774.

12. Veronelli A, Masu A, Ranieri R, et al. Prevalence of erectile dysfunction in thyroid disorders: comparison with control subjects and with obese and diabetic patients. Int J Impot Res. 2006; 18(1): 111-114, doi: 10.1038/sj.ijir.3901364, indexed in Pubmed: 16079903.

13. Abalovich M, Levalle $\mathrm{O}$, Hermes R, et al. Hypothalamic-pituitary-testicular axis and seminal parameters in hyperthyroid males. Thyroid. 1999; 9(9): 857-863, doi: 10.1089/thy.1999.9.857, indexed in Pubmed: 10524563.

14. Krysiak R, Drosdzol-Cop A, Skrzypulec-Plinta V, et al. Sexual function and depressive symptoms in young women with thyroid autoimmunity and subclinical hypothyroidism. Clin Endocrinol (Oxf). 2016; 84(6): 925-931, doi: 10.1111/cen.12956, indexed in Pubmed: 26426544.

15. Jostel A, Ryder WD, Shalet SM. The use of thyroid function tests in the diagnosis of hypopituitarism: definition and evaluation of the TSH Index. Clin Endocrinol (Oxf). 2009; 71(4): 529-534, doi: 10.1111/j.1365-2 265.2009.03534.x, indexed in Pubmed: 19226261.

16. Dietrich J, Landgrafe-Mende G, Wiora E, et al. Calculated Parameters of Thyroid Homeostasis: Emerging Tools for Differential Diagnosis and Clinical Research. Front Endocrinol. 2016; 7(57), doi: 10.3389/fendo.2016.00057, indexed in Pubmed: 27375554.

17. Dietrich JW, Müller P Schiedat F, et al. Nonthyroidal Illness Syndrome in Cardiac Illness Involves Elevated Concentrations of 3,5-Diiodothyronine and Correlates with Atrial Remodeling. Eur Thyroid J. 2015; 4(2): 129-137, doi: 10.1159/000381543, indexed in Pubmed: 26279999.

18. Rosen RC, Cappelleri JC, Gendrano N. The International Index of Erectile Function (IIEF): a state-of-the-science review. Int J Impot Res. 2002; 14(4): 226-244, doi: 10.1038/sj.ijir.3900857, indexed in Pubmed: 12152111.

19. Cappelleri JC, Rosen RC, Smith MD, et al. Diagnostic evaluation of the erectile function domain of the International Index of Erectile Function. Urology. 1999; 54(2): 346-351, indexed in Pubmed: 10443736.

20. Krysiak R, Marek B, Okopień B. Sexual function and depressive symptoms in young men with hypothyroidism receiving levothyroxine/lio- 
thyronine combination therapy. Endokrynol Pol. 2018; 69(1): 16-22, doi: 10.5603/EP.a2018.0005, indexed in Pubmed: 29319127.

21. Beck AT, Steer RA, Brown GK. BDI-II: Beck Depression Inventory Manual. 2nd ed. Psychological Corporation, San Antonio 1996

22. Krysiak R, Szwajkosz A, Marek B, et al. The effect of vitamin D supplementation on sexual functioning and depressive symptoms in young women with low vitamin D status. Endokrynol Pol. 2018; 69(2): 168-174, doi: 10.5603/EP.a2018.0013, indexed in Pubmed: 29442353.

23. Krysiak R, Drosdzol-Cop A, Skrzypulec-Plinta V, et al. Sexual functioning and depressive symptoms in women with various types of prediabetes - a pilot study. Endokrynol Pol. 2018; 69(2): 175-181, doi: 10.5603/EP.2018.0021, indexed in Pubmed: 29952425.

24. American Psychiatric Association. Diagnostic and statistical manual of mental disorders - DSM-IV-TR. 4th ed. American Psychiatric Publishing, Washington 1994.

25. Carosa E, Di Sante S, Rossi S, et al. Ontogenetic profile of the expression of thyroid hormone receptors in rat and human corpora cavernosa of the penis. J Sex Med. 2010; 7(4 Pt 1): 1381-1390, doi: 10.1111/j.1743-610 9.2009.01701.x, indexed in Pubmed: 20141582

26. Hu CL, Wu YD, Liu HT, et al. [Effect of thyroid hormone on the contents of NOS and CO in the penile corpus cavernosum of rats]. Zhonghua Nan Ke Xue. 2009; 15(1): 37-40, indexed in Pubmed: 19288747.

27. Ozdemirci S, Yildiz F, Utkan T, et al. Impaired neurogenic and endothelium-dependent relaxant responses of corpus cavernosum smooth muscle from hyperthyroid rabbits. Eur J Pharmacol. 2001; 428(1): 105-111, indexed in Pubmed: 11779026.

28. La Vignera S, Vita R, Condorelli RA, et al. Impact of thyroid disease on testicular function. Endocrine. 2017; 58(3): 397-407, doi: 10.1007/s12020-017-1303-8, indexed in Pubmed: 28429281.
29. Shea JL, Wong PY, Chen Yu. Free testosterone: clinical utility and important analytical aspects of measurement. Adv Clin Chem. 2014; 63 59-84, indexed in Pubmed: 24783351

30. Corona G, Isidori AM, Aversa A, et al. Endocrinologic Control of Men's Sexual Desire and Arousal/Erection. J Sex Med. 2016; 13(3): 317-337, doi: 10.1016/j.jsxm.2016.01.007, indexed in Pubmed: 26944463.

31. Smith TJ, Hegedüs L. Graves' Disease. N Engl J Med. 2016; 375(16): 1552-1565, doi: 10.1056/NEJMra1510030, indexed in Pubmed: 27797318.

32. Bové KB, Watt T, Vogel A, et al. Anxiety and depression are more prevalent in patients with graves' disease than in patients with nodular goitre. Eur Thyroid J. 2014; 3(3): 173-178, doi: 10.1159/000365211, indexed in Pubmed: 25538899.

33. Senturk T, Kozaci LD, Kok F, et al. Proinflammatory cytokine levels in hyperthyroidism. Clin Invest Med. 2003; 26(2): 58-63, indexed in Pubmed: 12722837.

34. Postal M, Appenzeller S. The importance of cytokines and autoantibodies in depression. Autoimmun Rev. 2015; 14(1): 30-35, doi: 10.1016/j. autrev.2014.09.001, indexed in Pubmed: 25242344.

35. Biondi B, Wartofsky L. Treatment with thyroid hormone. Endocr Rev 2014; 35(3): 433-512, doi: 10.1210/er.2013-1083, indexed in Pubmed 24433025 .

36. Klapcińska B, Poprzecki S, Danch A, et al. Selenium levels in blood of upper Silesian population: evidence of suboptimal selenium status in a significan percentage of the population. Biol Trace Elem Res. 2005; 108(1-3): 1-15, doi: 10.1385/BTER:108:1-3:001, indexed in Pubmed: 16327055

37. Szybiński Z. Polish Council for Control of Iodine Deficiency Disorders. Work of the Polish Council for Control of Iodine Deficiency Disorders, and the model of iodine prophylaxis in Poland. Endokrynol Pol. 2012; 63(2): 156-160, indexed in Pubmed: 22538756. 